\title{
Dynamic updating of learning events during a course on the basis of logbooks
}

\author{
Mikko Vanhatalo ${ }^{1}$, Tero Juuti ${ }^{2}$, Kaisu Rättyä ${ }^{3}$ \\ ${ }^{1}$ Faculty of Engineering and Natural Sciences, Tampere university \\ mikko.vanhatalo@tuni.fi \\ ${ }^{2}$ Faculty of Engineering and Natural Sciences, Tampere university \\ tero.juuti@tuni.fi \\ ${ }^{3}$ Faculty of Education and Culture, Tampere university \\ kaisu.rattya@tuni.fi
}

\begin{abstract}
In order to reach the deepest level of learning in university studies, different methods must be used in teaching to maximize interactivity. In this paper we present findings about utilizing logbooks, which are customized for the specific course implementation and how to use them in dynamic way to tailor learning events during the course. We are exploring the possibilities of using a reflective assessment tool like logbooks in our courses.

For the research strategy, we chose educational design research. Our research focuses on how we can benefit from logbooks in product development education. We have utilized logbooks on various courses. In some cases, they are used solely to enhance students' own reflection of the course content. The most comprehensive logbooks contain a number of course-specific questions and the contents of the logbooks are utilized on a continuous basis throughout the course to develop each learning event. The learning logs also highlighted metacognitive aspects, such as an awareness of personal product development skills, in area of concepting and industrial design. The logbooks reveal to the teachers how the students think and how they handle the course content.

The case course in this research is a masters level course called "Design Thinking and Industrial Design". The course assignment includes four different outcomes which effect to the grading. In addition, the logbook and the reflection students make of their own logbook is part of the grading. This emphasizes to students the importance of the contents of the logbook for their own learning. In many cases, students will only complete the course and its assignments without further reflection on the content of the course or their own learning and skills development during the course. The course-specific logbook and its active use in developing course learning situations deepen the students' understanding of the course content. The key findings were the increasing the depth of students learning, when they reflect their own work. It was also possible to update the content of learning events based of the issues the students find during the course.
\end{abstract}

Keywords: Logbook, metacognitive knowledge, sustainable assessment, feedback. 


\section{Introduction}

In this paper, we analyse students ' logbooks for master levels course „Desing Thingking and Industrial desing“ (5cr). It is based on Problem based and project based learning, studio-like working and authenthic work assignments. Learning logs presented by Barclay (Barclay 1996b) can be used as an assessment tool for students' learning experiences. This research focus on two different aspects of the logbooks: 1) to the form of the logbook to enhance the student learning during the course, and 2) to the utilisation of the logbooks to continuously react and to update the learning events based on the issues reported by the students. Problem based learning is a well-known and used method in higher education and specially in the product development area. (Savery et al. 1995, Hmelo-Silver et al. 2006). In our resent teaching development and research, we have been focusing on the students' reflection during the course implementation. We are exploring the possibilities of the logbooks to enhance the learning outcomes. The research strategy chosen here is educational design research presented by McKenney \& Reeves (McKenney, S., \& Reeves, T. C. 2012).

This research follows the generic model of educational design research (EDR) (McKenney \& Reeves, 2012; Reeves 2006). Our research consisted of different iterative phases of analysis and exploration, design and construction as well as evaluation and reflection. The project was carried out in autumn at 2019 at university for master level degree program. Earlier developed log book model (Rättyä 2016) was modified and tested in this study.

Engineering education at university faces challenge concerning the efficiency in producing high quality results in learning. Continuous improvement is executed on existing courses while novel content is introduced. What would be a fast and effective way to meet high quality with evolving content? Traditional way to develop a course is to collect feedback from the students when the course is finished. In best cases the students give well defined and justified development ideas, which gives detailed information what to develop and how. This is not beneficial in for the students during the course thus the corrections fall on to the next semester implementation. A more agile way is to collect quick feedback after a lecture to see if some topics were not described well enough and needs to be repeated at the following lecture.

The research questions in this study are:

1) What kind of form and structure of the logbook serves best the learning process during a course?

2) What kind of information learning logs give for teachers to develop and structure the course contents and instruction to help to reach the course aims?

\subsection{Logbook and learning logs}

The learning logs have been studied with different disciplines and they have been utilised for example in the product developers' communication. McAlmpine et al. stated in their study logbooks as a hub, through which the ideas and the information are collected and furthermore are connected into the use of the planning teams operation. In the study it was noticed that the logs produced information and rational to a richer one compared to the planning to traditional reports. (McAlpine, H. et. al 2017) Reflective texts, like learning journals, portfolios and learning logs, as assessment tools have been used in adult education and higher education effectively since 1990's when writing learning logs were described as relevant tools for selfdevelopment and professional development (Barclay 1996b). 
Learning logs can consist of an assigned number of log entries (self-reflective notes) during a learning period. With the help of structured learning log student can identify importance of learning process, create a consistent learning path, maximize the value of single learning events, recognize the individual learning processes, understand the responsibility of one's own development and find a forum for private and personal record of learning. (Barclay 1996a, 1996b; MacFarlane 2001.)

The use of learning logs as assessment methods has been combined with sustainable assessment, because sustainable assessment emphasis learning process and orientation towards future profession (Boud 2000; Boud \& Soler 2016). With sustainable assessment Boud and Falchikov (2006) as well as Boud and Soler (2016) lift up the purpose: "to equip student for their learning beyond the course". What comes to fostering reflexivity and it's meaning for learning, goals for sustainable assessment are that student learn how to act in authentic work situation, understands own knowledge base and skills, learning how to develop reflectivity and involvement.

\section{The case course implementation}

The case course aims to teach to the students the importance to understand how industrial design effects on the company brand and how customers and their impressions should be managed in product development. The course can be taken as individual work or by the pair, and it includes four outcomes related to the development work and in addition a logbook which has to be filled on weekly basis. The weekly teaching contained a three hour session, which proceeded as follows. 1) The teachers presented the mostly mentioned issues what the students had reported in the logbooks. These issues were discussed with the students and they were able to ask more detailed questions. 2) The teachers presented new tools and methods, or repeated previously presented ones, to give students new viewpoints and more information about the reported issues. 3) The students shortly upgrade their assingments on the area where they had issues in. 4) The teachers presents material for the next steps of the assingment. 5) The students work on the new matters and they can ask for more advise if necessary.

The learning objectives (figure 1) for this course are focusing on understanding the industrial design and to its implementation. After the course students should:

- understand and be able to create product concepts and their presentations according to the company design

- be able to create multiple sketches with different tools

- understand the meaning of industrial design from customer point of view

- understand how the industrial design effects on the brand of the company. 


\begin{tabular}{|c|c|c|c|c|}
\hline \multirow[b]{2}{*}{ Taxonomy } & \multirow{2}{*}{$\begin{array}{c}\text { Conceptual } \\
\text { Conceptual knowledge, } \\
\text { mental models }\end{array}$} & \multicolumn{3}{|c|}{ Procedural, mini processes, steps in the methods } \\
\hline & & Industrial design & Design thinking & Concepting, skething \\
\hline Create & $\begin{array}{l}\text { Is able to plan and } \\
\text { implement a mini } \\
\text { project }\end{array}$ & $\begin{array}{l}\text { Can create a product } \\
\text { concept according to a } \\
\text { company design }\end{array}$ & \multicolumn{2}{|c|}{ Can create a dicital sketch / prototype } \\
\hline Analyze & & $\begin{array}{l}\text { Can utilise designs } \\
\text { format analysis to } \\
\text { company's products }\end{array}$ & $\begin{array}{l}\text { can get and can analyse } \\
\text { feedback to the form } \\
\text { language and product } \\
\text { concept }\end{array}$ & $\begin{array}{l}\text { can analyse the } \\
\text { concpets by different } \\
\text { methods }\end{array}$ \\
\hline Apply & $\begin{array}{c}\text { can adapt the methods } \\
\text { of the participatory } \\
\text { design in practice in the } \\
\text { project }\end{array}$ & $\begin{array}{c}\text { Can utilise the analysis } \\
\text { tools of the form } \\
\text { language and of the } \\
\text { brand }\end{array}$ & $\begin{array}{l}\text { Can adapt Observe and } \\
\text { the Understand tools in } \\
\text { the design process }\end{array}$ & $\begin{array}{l}\text { Can adapt different } \\
\text { creativity techniques }\end{array}$ \\
\hline Understand & & & $\begin{array}{l}\text { can demonstrate and } \\
\text { udesrtands the needs } \\
\text { and demands for the } \\
\text { customer segment }\end{array}$ & \\
\hline Taxonomy & & Metacognitive & Affect /Emonational skills & \\
\hline \multirow[t]{2}{*}{ Create } & Poster & $\begin{array}{c}\text { Consciousness of own } \\
\text { thinking, learning and self- } \\
\text { regulation }\end{array}$ & $\begin{array}{l}\text { Consciousness of the } \\
\text { tunnetila, motivation }\end{array}$ & \\
\hline & $\begin{array}{l}\text { Can create a poster } \\
\text { following company's } \\
\text { design guidelines }\end{array}$ & & & \\
\hline Analyze & $\begin{array}{c}\text { can analyse the graphic } \\
\text { regulations of the } \\
\text { company }\end{array}$ & $\begin{array}{c}\text { Can choose the tools } \\
\text { suitable to the research } \\
\text { questions }\end{array}$ & $\begin{array}{c}\text { can weigh the ethical } \\
\text { questions of the } \\
\text { development project and } \\
\text { their effect on the own } \\
\text { operation }\end{array}$ & \\
\hline Apply & $\begin{array}{l}\text { can utilise the graphic } \\
\text { regulations of the } \\
\text { company }\end{array}$ & $\begin{array}{l}\text { Can recognise own } \\
\text { learnign talens, time } \\
\text { management and self- } \\
\text { regulation skills }\end{array}$ & $\begin{array}{l}\text { Can operate in its } \\
\text { discomfort area and can } \\
\text { analyse feelings and } \\
\text { motives which are } \\
\text { related to it }\end{array}$ & \\
\hline Understand & & $\begin{array}{l}\text { To understands the } \\
\text { basic skills of the } \\
\text { engineer to create } \\
\text { several alternatives }\end{array}$ & $\begin{array}{c}\text { understands that the } \\
\text { feelings will come and go }\end{array}$ & \\
\hline
\end{tabular}

Figure 1. Learning objectives of the case course

The course implementation includes four different outputs required from the students.

1. Design thinking - is there a product missing from the markets? Students choose a brand and then innovate a new product concept to the company portfolio. The main focus will be in the following outputs to focus on the design of the product. E.g. if a motorcycle manufacturer Ducati would design a car, what it would look like? Or if the forestry manufacturer Ponsse would design a chainsaw? Part of this task is to define customer segment and plan how the students can make a customer survey about their ideas.

2. DFA - Desing Format Analysis (Karjalainen, T. M. 2007, Eroglu i., et. al 2017) - is a method to define and rate the design and its characteristics. Student perform the analyzing to their case brand products and utilizes the results in their product ideas and also in the other outcomes of the course, like the concept presentation to the "executive team" and final poster. 
3. Concept definition - includes multiple sketches $(+50)$ about the design of the product, and about the details which bring the novelty to the students' concept. These concepts have to follow the company design language and visual impressions. All the designs requirements, ideas and details are collected to presentation for the "management team". The presentation has to mimic the graphical expression of the chosen company.

4. Poster - is the final outcome which is presented at the end of the course. As the previous outcomes, it has to look like it is done by the company representatives. Meaning that the poster should follow the company brand and marketing material.

\subsection{Case logbook}

Logbooks has been used in our previous course implementations, but they have been more generic versions. They contained questions e.g. like: what challenges there is? and what did you learn this week? This is probably one reason why the answers in the logbooks were shorter and shallow in content. For the last course implementation, the logbook questions were changed to fit better to the course content and in addition the content of the logbook influenced to the course grading.

\begin{tabular}{|c|l|l|l|}
\hline \multicolumn{1}{|c|}{ MEI-46402 DT ja Teollinen Muotoilu } & \multicolumn{1}{|c|}{ week 1 } & week 2 \\
\hline \multirow{4}{*}{$\begin{array}{c}\text { Group } \\
\text { Section }\end{array}$} & What we did at this week? & & \\
\cline { 2 - 4 } & $\begin{array}{l}\text { What tools was used? } \\
\text { had thin at week? }\end{array}$ & & \\
\cline { 2 - 4 } & $\begin{array}{l}\text { What is causing the most } \\
\text { issues at the moment? }\end{array}$ & & \\
\cline { 2 - 4 } & $\begin{array}{l}\text { What did we learn as a } \\
\text { pair? }\end{array}$ & & \\
\hline
\end{tabular}

\begin{tabular}{|c|l|l|l|}
\hline \multirow{4}{*}{$\begin{array}{c}\text { Personal } \\
\text { section } \\
\text { Student } 1\end{array}$} & $\begin{array}{l}\text { The biggest challenge for } \\
\text { me was? }\end{array}$ & & \\
\cline { 2 - 4 } & $\begin{array}{l}\text { How has my skills about } \\
\text { industrial design evolved? }\end{array}$ & & \\
\hline & $\begin{array}{l}\text { How has my shelf- } \\
\text { regultaion skills evolved? }\end{array}$ & & \\
\hline
\end{tabular}

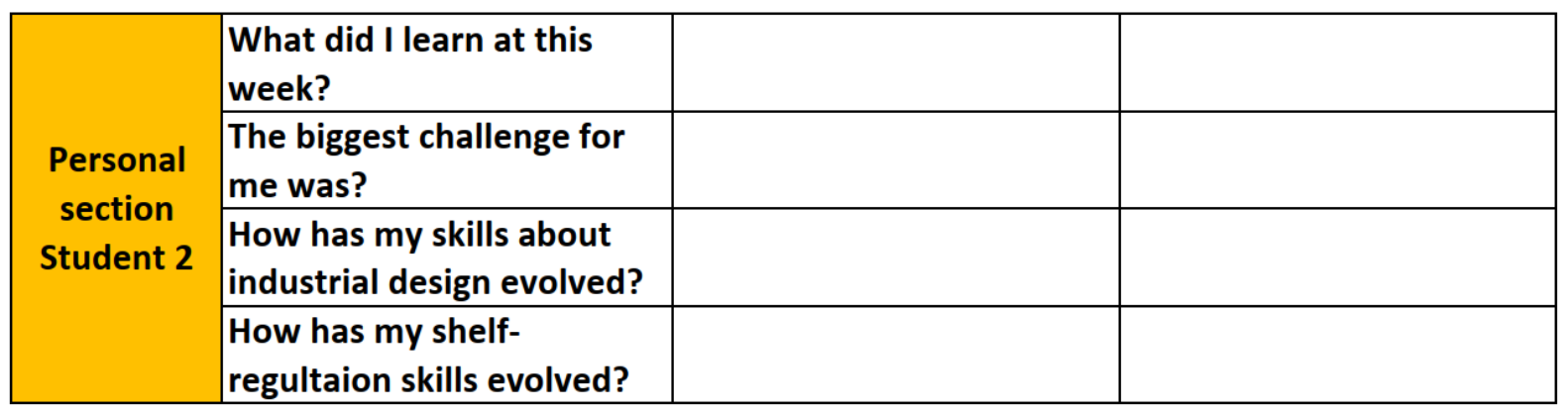

Figure 2. Logbook template for the students 
The logbook template was an Excel sheet. It was given to the student on the course Moodleplatform, in which the students also returned the filled version of the logbook. To get the most benefit from the logbooks they were read on a weekly basis. The deadline for students was every Friday at noon. The learning events (design studio) was at Mondays at 10-13. There was enough time for the teachers to react. If there were some common issues among the students the teachers prepared material and discussion for the beginning of learning event.

\section{Data}

The data for this research is the student's logbooks from the case course. The students were asked for permission to use their logbooks anonymously in this research. There were 16 projects at this course. 11 of them was made in pairs and 5 students chose to work alone. The logbook presented in figure 2 was provided as a template for students. In case of pair work, pairs answered together on the group section and individually to the personal section. Each week they added new column to the table. Thus there was all together nearly 160 cells of information. As presented earlier, the new content of the logbooks was analysed weekly. The final column in the logbook contained students own analyse about their learning presented by them and also analysis of their course outcomes

Table 1. Most reported issues about the course assignments.

\begin{tabular}{|l|l|c|}
\hline week & Issues & $\begin{array}{c}\text { occunsces } \\
\text { (out of 16) }\end{array}$ \\
\hline 1 & Finding interesting topic and brand for the assignment. & 10 \\
\hline 2 & Learning the way out of typical "first idea is the best" thinking & 8 \\
\hline 3 & "Mini research". Where to find customer information & 12 \\
\hline 4 & Getting started with sketching. What tools to use for sketching. & 11 \\
\hline 5 & Data search for the mini research & 11 \\
\hline 6 & Enhancing the quality of the sketches & 9 \\
\hline 7 & Making of Design format analysis & 9 \\
\hline 8 & Merging of technical aspects and the design & 7 \\
\hline 9 & Defining the expression of form to the final presentations & 6 \\
\hline 10 & Creating the final images and their rendering & $\begin{array}{l}\text { Time resources for finishing all the assignments. Focusing to the } \\
\text { relevant tasks }\end{array}$ \\
\hline 11 & Fitting the final poster to the case company visual & 9 \\
\hline 12 & & 9 \\
\hline
\end{tabular}


For an individual student the biggest development areas were self-regulation skills and the development of the observation of the design of products. Several students commented that they had not thought about the significance of the design of the product or brand to the company earlier. From the prodcut development point of view it was pleasent to see that the students" abilites for problem solving and decision making also evolved.

At the beginning of the course, there was surprisingly many students who had issues with the self-regulation skills. In majority of the logbooks it was reported that the students had difficulties to book enough time to work with the assignments. The reaction for this was to show different tools for managing project and time schedules. Also, methods how to focus on the more important factors and how to define those.

\section{Results}

The logbooks was one basis of the evaluation of the course performing. Thus the students produced largely covering analysis about their work and the students made exemplary and profound considerations from their learning. The correlation between the set objectives of learning and what the students reported was strong.

Based on the content analysing below are the most indicated areas of students " progression:

- Evolving in skeching techniques

- Understanding desing format and why it is important

○ Beginning to look products from industrial design point fo view

- Self-regulation skills imporved greatly.

- Enhanced skills in problem definition and especially finding and valuing solutions to come up with the best possible outcome.

The final task of the course for the students was to review their own logbook and summarise how it effected on thier learning, or did it affect at all. Nearly all of the students reported logbooks to improve their learning, as they were forced to actually think what they have done at the assingment and learning events, and also think what is the area where to focus most.

RQ1: What kind of form and structure of the logbook serves best the learning process during a course?

The case logbook was designed to emphasise the course learning objectives. Based on the student though flow and considerations, it is possible to conclude that the students worked more deeply on their assignments. It was noted in earlier course implementations that students just carried out the given tasks without any detailed pondering of the topics. There was discussion with the students about the role and effects of the logbooks. Majority of the students participating to the conversation stated that the logbooks motivated them to justify their solutions at the assignment.

The logbook structure highlighted as well the issues related to the content of the assignment outcomes as the issues individual student had related to their pair work as self-regulation skills. The columns filled weekly by the students enabled the teachers to get information about the students assignments situation and also highlight the issues related to students own performing. 
RQ2: What kind of information logbooks give for teachers to develop and structure the course contents and instruction to help to reach the course aims?

As previously stated, the logbooks included detailed thoughts of the students at every week. This information allowed teachers to give specific instruction at the beginning of each learning event. Thus, the student gets the most focused information and material at the best possible time.

As an example, one very common comment was the difficulties to be able to create enough sketches. In the assignment there was demand to create at least 50 sketches, which is quite low number considering that the course topic is industrial design. To enhance the students' situation an extra time was pointed to practice sketching skills. During the exercise students practiced sketching techniques and used ideation cards to find more alternatives for their ideas.

Another fairly surprised issue reported by the students, was the lack in the self-regulation skills. Many reported that they did not find enough time for the assignments. The logbooks revealed that students rarely actually booked any time for specific tasks related to this course. They did these tasks when ever happened to be free slot and at most cases very close to the given deadlines. To react to this issue the teachers presented examples how to divide work in to manageable portions so it is possible to book a time for each smaller task. This requires planning from students themselves, which on the other hand forces them to think about the course topic.

An important part of our course development is to carefully go thru the feedback from the students after the course to ensure, that the next course implementation will be better compared to the previous one. This case course implementation revealed how students proceed in their assignment and what were the bottlenecks at the assignment progress. This is a valuable asset to our development process. Compared to the earlier course implementations, teachers received this information at the end of the course, when it was too late to react.

\section{Discussion}

We have utilized logbooks in multiple course implementations from the first year students courses all the way to the last courses of product development curriculum. The scope and the scale of logbooks have varied. The latest study was to see how the targeted lokbook questions effect on the students' reflection and how we can use these in the most beneficial way.

Our logbook development has followed the generic model for conduction design research in education presented by McKenney \& Reeves seen in figure 3. Logbooks are used widely in our teaching for few years' time. The first logbooks were simple versions which had basic questions like "what was difficult?" and "what did you learn?". The next version had more focused questions about the course content, but the logbooks were evaluated at the end of the course. 


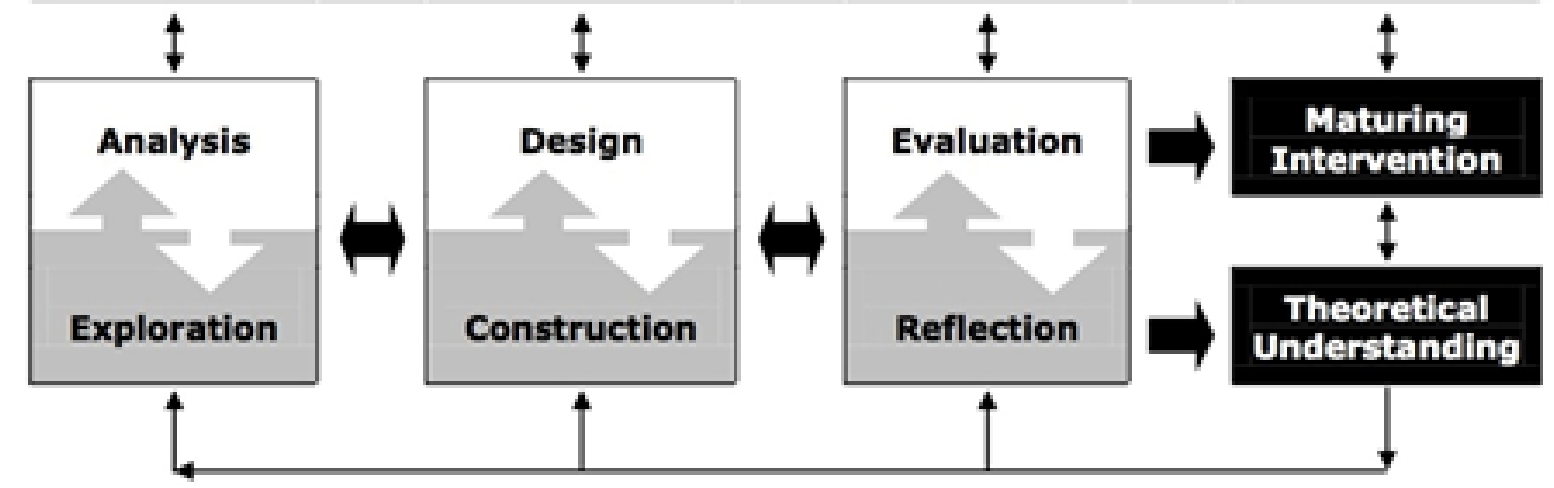

Figure 3. Generic model for conducting design research in education (McKenney \& Reeves, 2012)

At the current state we utilized the logbooks to actively react on students' issues and lack of information or skills required to the course assignment. We have good understanding about the possibilities of the logbooks and different options to use them.

\section{Conclusions}

The logbooks are valuable asset on gathering profound information about the students during the course implementation. Our understanding about the possibilities has grown vastly and we have found new ways to use the logbooks. The future work will be about more dynamic logbooks. So far, the logbooks have had the same questions throughout the course implementation. There are grounds for that kind of logbook utilization, but in many cases it would be beneficial to actively update the questions in the logbook based on the different situation on the assignment and also based on the students skills and on their development. 


\section{Citations and References}

Barclay, J., Learning from experience with learning logs, The Journal of Management Development; Bradford Vol. 15, Iss. 6, (1996): 28-43. 1996a

Barclay, J. "Assessing the benefits of learning logs," Educ. + Train., vol. 38, no. 2, pp. 30-38, Mar. 1996b

David B., (2000) Sustainable Assessment: Rethinking assessment for the learning society, Studies in Continuing Education, 22:2, 151-167

David B. \& Rebeca S., (2016) Sustainable assessment revisited, Assessment \& Evaluation in Higher Education, 41:3, 400-413

Eroglu, I., Kacar, D., Esen, Ö., A Study On Correlation Between Brand Identity Integrity And Innovation Capabilities, NordDesign 2016, August, 2016, Trondheim, Norway

Hmelo-Silver, C. E. \& Barrows, H. S., "Goals and Strategies of a Problem-based Learning Facilitator," Interdiscip. J. Probl. Learn., vol. 1, no. 1, pp. 21-39, 2006.

Karjalainen, T. M. (2007). It looks like a Toyota: Educational approaches to designing for visual brand recognition. International Journal of Design, 1(1), 67-81.

McAlpine, H., Cash, P., Hicks, B., The role of logbooks as mediators of engineering design work, Design Studies, Volume 48, 2017, Pages 1-29

McKenney, S., \& Reeves, T. C. (2012). Conducting Educational Design Research. Abingdon: Routledge.

Reeves, T. C. (2006). Design research from a technology perspective. In J. van den Akker, K. Gravemeijer, S. McKenney \& N. Nieveen (Eds.), Educational design research (pp. 5266). London, England: Routledge.

Savery, J. R., \& T. M. Duffy, "Problem based learning: An instructional model and its constructivist framework," Educ. Technol., vol. 35, no. 5, pp. 31-38, 1995.

Rättyä, K., "Lokikirja ainedidaktisten opintojen arviointimenetelmänä," in Ainedidaktinen symposium "Uudistuva ja uusiutuva ainedidaktiikka, 2016. 